\title{
UNIVERSITY OF PENNSYLVANIA RADIOCARBON DATES XXI
}

\author{
ANNE MEULENGRACHT, PATRICK McGOVERN, \\ and BARBARA LAWN
}

Department of Physics, University of Pennsylvania, Philadelphia, Pennsylvania 19104

\section{INTRODUCTION}

This date list includes most of the archaeologic and geologic samples dated in this laboratory since publication of our last date list (R, 1978, v 20, p 210-233), as well as some samples dated previously which lacked adequate sample information.

The BP ages are based on AD 1950, and have been calculated with the half-life value of $5568 \mathrm{yr}$. All samples were counted at least twice for periods of not less than $1000 \mathrm{~min}$ each. Errors quoted for each sample include the sum of the statistical counting uncertainties in the measurement of the sample, the background, and several counts of our mid-19th century AD oak sample, but do not include the possible half-life errors.

The MASCA corrected dates which appear in the comments were obtained by applying appropriate correction factors based upon treering-dated samples to dates calculated with the 5730 half-life, but do not include any additional errors associated with the correction factors. For further explanation, see University of Pennsylvania Dates XVI (R, 1974, v 16, p 198-218) and Ralph, Michael, and Han, 1973.

In addition to our $28 \mathrm{~L}$ counters, a small $1 \mathrm{~L}$ counter is employed for counting undersized samples. Larger errors associated with these dates are a direct result of small sample size and consequently reduced number of counts. Use of the small counter is indicated in individual sample comments. In all counters we continue to use pure $\mathrm{CO}_{2}$.

All samples were pretreated with $3 \mathrm{~N} \mathrm{HCl}$ and some, where noted, were given additional pretreatment with $2 \% \mathrm{NaOH}$ for the removal of possible humic acid contaminants.

Ages have been calculated with the use of our mid-19th century AD calibration samples which have an average age of $145 \mathrm{yr}$. When calibrated for this age, these calibration samples have ${ }^{14} \mathrm{C}$ contents equal to $95 \%$ of the NBS oxalic acid standard. The average $\delta^{13} \mathrm{C}$ relationship between the oak standard and the NBS limestone standard \#20 is -24.95 \pm $0.23 \%$ as measured on this laboratory's Micromass 622 mass spectrometer. Where $\delta^{13} \mathrm{C}_{\mathrm{w}}$ is reported, the $\delta^{13} \mathrm{C}$ relationship has been measured with respect to the oak standard and the results corrected accordingly for isotopic fractionation.

\section{SAMPLE DESCRIPTIONS}

\section{ARCHAEOLOGIC SAMPLES}

Czechoslovakia

\section{Valěa, Slovakia series}

Wood samples from layer of chernozem with inclusions of peat and wood from Valča, Czechoslovakia (ca $49^{\circ} 10^{\prime} \mathrm{N}, 19^{\circ} 30^{\prime} \mathrm{E}$ ). Coll and 
subm 1977 by Vaclav Bucha, Československá Akad věd Geofysikální Ústav, Prague.

\section{P-2712. Sample 1}

$\mathbf{5 2 5 0} \pm \mathbf{2 4 0}$ ments: sample counted in small counter. MASCA corrected date: 4120, 4090 to $4070 \pm 250$ BC. (VB): likely date ca $4000 \mathrm{yr}$ BP.

\section{P-2713. Sample 2}

$\mathbf{5 5 3 0} \pm \mathbf{8 0}$

Wood at $4.6 \mathrm{~m}$ depth as measured on slanting profile (cut) ments: MASCA corrected date: $4430 \pm 80$ BC. (VB): likely date ca 5300 yr BP.

\section{Ireland}

$$
2210 \pm 40
$$

P-2737-A. Reask, Co Kerry, Sample $170 \quad \delta^{13} C_{w}=+0.13 \pm 0.22 \%$

Charcoal from Reask, Co Kerry, SW Ireland ( $\left.52^{\circ} 6^{\prime} \mathrm{N}, 7^{\circ} 30^{\prime} \mathrm{W}\right)$. Sample is from Structure G, Sq 4, E side of Early Monastic Enclosures. Coll 1975 by Thomas Fanning; subm 1975 by Kathleen Ryan, MASCA, Univ Mus, Univ Pennsylvania, Philadelphia. Comments: NaOH pretreatment. MASCA corrected date: $400 \pm 40$ BC. (TF): expected date ca AD 600 (Fanning, 1973; 1975).

\section{Dhali-Agridhi series}

\section{Cyprus}

Samples are from Neolithic site of Dhali-Agridhi, ca $18 \mathrm{~km} \mathrm{~S}$ of Nicosia, Cyprus (35 $2^{\prime} \mathrm{N}, 33^{\circ} 26^{\prime} \mathrm{E}$ ) and represent both Aceramic and Ceramic phases. Coll and subm 1976 by Y M Lehavy, Atlantic Co Community Coll New Jersey.

General Comment (YML): site is important for establishing chronology of Neolithic Cyprus. Dhali-Agridhi's Aceramic phase is contemporaneous with Aceramic Khirokitia, yet different in character (Lehavy, 1974).

\section{P-2769. Sample 3}

$5700 \pm 100$

Charred bone from Area 2, Loci 21 and 24, Layer III, Concentration A. Comments: MASCA corrected date: $4560 \pm 100$ BC. (YML): found with high concentration of Dark Faced Burnished Ware, which is earliest known pottery in Cyprus. Previous ${ }^{14} \mathrm{C}$ date for same deposit: GX-2847A, $4465 \pm 310$ вс (Lehavy, 1974, p 98).

\section{P-2768. Sample 2}

$7400 \pm 60$

Charcoal and charred bone from Area E, $200 \mathrm{~m}$ W of original site under paved floor. Comment: date beyond range of MASCA correction factors now available (Oct 1980).

\section{P.2775. Sample 1}

$7990 \pm 80$

Charred bone mixed with charred material and soil from Area 12, Loc 008, Layer III, Concentration B. Sample is from lowest loc in deposit, next to a pit. A few fragments of stone bowls assoc with sample. 
Comments: date beyond range of MASCA correction factors now available (Oct 1980). Previous date for same deposit: GX-2848-A, $5340 \pm 465$ BC (Lehavy, 1974, p 98).

\section{Kampia mining area series}

Possible ancient mine at Kampia, Cyprus $\left(35^{\circ} 12^{\prime} \mathrm{N}, 33^{\circ} 15^{\prime} \mathrm{E}\right)$. Coll and subm 1977 by J D Muhly, Dept Ancient Hist, Univ Pennsylvania, Philadelphia.

General Comment (JDM): mine possibly of Roman date.

P-2716. Pekisterka ore body $\quad \begin{array}{r}2240 \pm 60 \\ \delta^{13} C_{w}=+14.57 \pm 0.47 \% 0\end{array}$ Rope. Comment: $M A S C A$ corrected date: $410 \pm 60 \mathrm{BC}$.

P-2720. Pitharochoma ore body, Sample $A \quad 2260 \pm 40$

Timber support. Wood id by R C Koeppen, Forest Prods Lab, USDA, Madison, Wisconsin, as pine, halepensis type. Comment: MASCA corrected date: $410 \pm 40 \mathrm{BC}$.

P-2721. Pitharochoma ore body, Sample B $\quad 2440 \pm 60$

Timber support. Wood id same as P-2720 (see above). Comment: MASCA corrected date: 710 to $690,530 \pm 60 \mathrm{BC}$.

P-2719. Mitsero

$1510 \pm 170$

Charcoal from copper smelting furnace at Mitsero, Cyprus $\left(35^{\circ} 12^{\prime}\right.$ N, 33० 12' E). Coll and subm 1977 by J D Muhly. Comments: sample counted in small counter. MASCA corrected date: $\mathrm{AD} 460$ to $480 \pm 170$. (JDM): furnace possibly of Roman date.

\section{Akrotiri series III}

\section{Greece}

Samples from important Bronze Age settlement at Akrotiri on volcanic i. of Thera (Santorini) $\left(36^{\circ} 16^{\prime} \mathrm{N}, 25^{\circ} 27^{\prime} \mathrm{E}\right)$, Cyclades, Greece. Coll 1976 by Christos Doumas, Ministry Culture and Sci, Athens; subm 1978 by $\mathrm{H}$ N Michael. For analyses of this and two previous series (R, 1977, v 19, p 191-193; R, 1978, v 20, p 215-216), see Betancourt and Weinstein, 1976; Michael, 1976; 1978; Weinstein and Betancourt, 1978; Weinstein and Michael, 1978.

General Comment: all samples are from $\mathrm{Rm} 5$ in $\mathrm{W}$ House.

\section{P.2791. Sample 1976.9}

$3340 \pm 60$

Seeds and charred material from Jar $\pi 2, \Delta 1$. Comment: MASCA corrected date: 1710 to $1690 \pm 60 \mathrm{BC}$.

\section{P-2792. Sample 1976.10}

$3670 \pm 180$

Volcanic ash and organic material from $\Delta 1$. Comments: sample counted in small counter. MASCA corrected date: $2150 \pm 190 \mathrm{BC}$. 
P.2793. Sample 1976.11

$3300 \pm 140$ small counter. MASCA corrected date: $1660 \pm 140 \mathrm{BC}$.

\section{P-2794. Sample 1976.12}

$\mathbf{3 1 8 0} \pm \mathbf{5 0}$ to $1510 \pm 50$ BC.

\section{P-2795. Sample 1976.13}

$\mathbf{3 3 8 0} \pm \mathbf{1 7 0}$ sample counted in small counter. MASCA corrected date: 1750 to 1710 $\pm 180 \mathrm{BC}$.

\section{P-2717. Plagiada}

$3180 \pm 45$

Charcoal from the Bronze Age site of Plagiada, near Myrtos in SE Crete $\left(35^{\circ} 0^{\prime} \mathrm{N}, 25^{\circ} 30^{\prime} \mathrm{E}\right)$. Sample is from villa, probably of LMIB date. Coll and subm 1977 by J D Muhly. Comment: MASCA corrected date: $1540,1510 \pm 50$ вс.

\section{Grotta dell'Uzzo series}

$$
\text { Italy }
$$

The natural cave of Grotta dell'Uzzo located between Castellammare del Golfo and San Vito lo Capo, Sicily (38 $\left.6^{\prime} 35^{\prime \prime} \mathrm{N}, 0^{\circ} 20^{\prime} 3^{\prime \prime} \mathrm{E}\right)$. Mesolithic levels were found in interior of cave and its talus, a Neolithic deposit outside cave (Segre and Piperno, 1975). Samples coll 1975 and 1977 and subm 1977 by Marcello Piperno, Inst Italiano Paleontol Umana, Rome.

General Comment: all samples are charcoal and all dates are beyond range of MASCA correction factors now available (Oct 1980).

\section{P-2733. Sample 1977-1}

$$
6750 \pm 70
$$
Assoc with Neolithic impressed and stamped pottery of pre-Stentinello type, lithic industries with some obsidian, as well as faunal and especially fish remains.

\section{P-2734. Sample 1977-2}

$7910 \pm 70$

Sample from Trench $\mathrm{F}$, Cuts 13 and 14 , representing intermediate Aceramic level between ancient Neolithic and Epipaleolithic levels. Assoc with lithic industries, wild faunal, and especially fish remains. Comment: $\mathrm{NaOH}$ pretreatment.

\section{P.2735. Sample 1977-3}

$\mathbf{8 3 3 0} \pm \mathbf{8 0}$ tries are scarce. Comment: $\mathrm{NaOH}$ pretreatment. 
P-2556. Sample 1975-1

$9030 \pm 100$

Sample from Trench A, Cut 7, representing Upper Mesolithic cultural horizon. Assoc with lithic industries, especially a unique type of end-scraper.

P-2557. Sample 1975-2

$9180 \pm 100$

Sample from Trench A, Cut 16. For assoc, see P-2556 (above). Comment: $\mathrm{NaOH}$ pretreatment.

P-2558. Sample 1975-3

$9300 \pm 100$

Sample from Trench C, Cut 3, representing Lower Mesolithic horizon. Assoc with lithic industries and faunal remains.

P-2736. Sample 1977-4

$10,070 \pm 90$

Sample from Trench G, Cut 9, large ash mound overyling filling of Grave Uzzo 5. Represents beginning of Mesolithic occupation of cave and assoc with lithic industries. Comment: this is earliest sample from cave.

\section{P-2789. Orsanmichele \\ $\mathbf{4 0 0} \pm \mathbf{4 0}$}

Seeds of sunflower family, rose family, and one unidentifiable type (id by R J Tyrl, Biol Sci Dept, Oklahoma State Univ, Stillwater) from Medieval church of Orsanmichele, Florence, Tuscany $\left(43^{\circ} 30^{\prime} \mathrm{N}, 11^{\circ} 0^{\prime}\right.$ E). The 14th century church was built for dual purpose of worship and storage and selling of grain. Sample came from grain shoot in church, ca $4 \mathrm{~m}$ above ground level. Coll 1978 by D F Zervas, Mount Holyoke Coll, Massachusetts; subm 1978 by M B Kirkham, Dept Agronomy, Oklahoma State Univ, Stillwater. Comments: MASCA corrected date: AD $1440 \pm 40$. (DFZ): date confirms hypothesis that seed was actually stored in church until 15 th century.

\section{P-2788. Ortu Cómidu, Area $S \quad 3310 \pm 50$}

Charcoal from Ortu Cómidu, Sardara (Prov Cagliari), Sardinia $\left(38^{\circ} 36^{\prime} \mathrm{N}, 8^{\circ} 50^{\prime} \mathrm{E}\right)$. Site is complex of stone structures with Nuraghic and Punic material (Taramelli, 1918). Sample is from earliest area of complex, a purely Nuraghic context beneath pavement of Area S, S tower of nuraghe (Balmuth and Tylecote, 1976). Coll and subm 1976 by M S Balmuth, Tufts Univ, Medford, Maine. For previous series, see R, 1977, v 19, p 194. Comments: MASCA corrected date: $1680 \pm 50$ вC. (MSB): sherds found in assoc with sample seem identical with 8 th century BC vessel found in Vetulonia, but see Bernabo Brea, 1980, p 197, for possible 12th or 11 th century вС date of similar wares.

\section{P.2714-A. Abydos}

\section{Egypt}

Sample is from outermost coffin of Lady Sat-Nub (Body 9, Tomb 3)

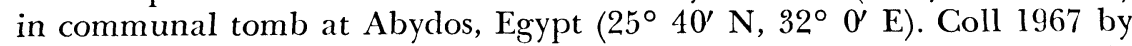
David O'Connor; subm 1977 by Bernard Fishman, Univ Mus, Univ 
Pennsylvania, Philadelphia. Wood id by B F Kukachka, Forest Prods Lab, Madison, Wisconsin, as genus Minusops of family Sapotaceae. Comments: $M A S C A$ corrected date: $800 \pm 60 \mathrm{BC}$. $(\mathrm{BF}):$ coffin is probably earliest burial in tomb and may date its construction. However, wood may have been re-used. Date of tomb on stylistic grounds is ca 675 BC.

\section{Tal-i Kureh series}

\section{Iran}

Tal-i Kureh is prehistoric site in Marv Dasht, Fars Prov, Iran $\left(30^{\circ}\right.$ $\left.12^{\prime} 30^{\prime \prime} \mathrm{N}, 52^{\circ} 14^{\prime} 0^{\prime \prime} \mathrm{E}\right)$. Samples coll 1977 by John Alden, Mus Anthropol, Univ Michigan, Ann Arbor; subm 1977 by R H Dyson, Jr.

General Comment: samples counted in small counter.

\section{P-2624. Sample No. 7F1-Lot 10}

Charcoal from Upper Stratum VII, Terminal Lapui phase. Comment: $M A S C A$ corrected date: $3770 \pm 300$ BC.

\section{P-2627. Sample No. 7F1-Lot 9}

Charcoal from Lower Stratum V, Initial Banesh phase. Comments: $M A S C A$ corrected date: $3150 \pm 240$ BC. (JA): this sample with P-2626 (see below) dates beginning of Banesh period in Fars (ca 3400 BC), further supported by ceramic parallels with Susa Acropole Level 17.

P-2626. Sample No. 7F1-Lot 8

$\mathbf{4 5 5 0} \pm \mathbf{2 8 0}$

Charcoal from Stratum V, Initial Banesh phase. Comments: $M A S C A$ corrected date: 3370 to $3350 \pm 280$ BC. (JA): same as for P-2627 (above).

\section{P-2718. Tel Michal}

Israel

Charcoal sample from sand pit, $40 \mathrm{~cm}$ below upper contact at Tel Michal, $\mathrm{N}$ of Tel Aviv, Israel $\left(32^{\circ} 10^{\prime} \mathrm{N}, 34^{\circ} 45^{\prime} \mathrm{E}\right)$. Coll and subm 1977 by J D Muhly. Comments: MASCA corrected date: aD $1630 \pm 40$. (JDM): pit possibly from Persian period (mid-first millennium BC). No explanation for young date obtained.

\section{Ras al-Hamra series}

\section{Oman}

Prehistoric shell mound at Ras al-Hamra in Wadi Qurm coastal area, $13 \mathrm{~km} \mathrm{~W}$ of Muscat, Sultanate of Oman $\left(26^{\circ} 13^{\prime} 38^{\prime \prime} \mathrm{N}, 65^{\circ} 9^{\prime} 0^{\prime \prime} \mathrm{E}\right)$. Mound was excavated in rescue operation and is 1 of at least 10 middens along coast belonging to aceramic Ras al-Hamrian horizon (Tosi, 1975). All samples except P-2673 and P-2738 coll and subm 1977 by Maurizio Tosi, Inst Univ Orientale, Naples.

General Comments: all samples are charcoal. (MT): series is first for Sultanate of Oman, and site is first aceramic coastal site found in Persian Gulf or Arabian Sea area. Proposed date for horizon is 6000 to $4000 \mathrm{BC}$; results are unexpectedly young. 


\section{P-2673. RH 2}

$4030 \pm 70$

Sample from Site RH 2, coll randomly at surface and without clear strat assoc, by $\mathrm{R}$ Jäckli, 1974. Comment: MASCA corrected date: 2680 to $2630 \pm 70 \mathrm{BC}$.

P.2738. Sample 7

$$
4170 \pm 220
$$

Sample from Site RH 2, coll randomly at surface by R Jäckli, 1975. Comments: sample counted in small counter. MASCA corrected date: $2910 \pm 220$ BC.

\section{P-2739. Sample 6}

$5140 \pm 200$

Sample from Site RH 4, Area 11, Stratum 2. Assoc with animal bones and other food remains as well as stone and shell necklace. Comments: sample counted in small counter. MASCA corrected date: 3960 to $3940 \pm 200 \mathrm{BC}$.

P-2740. Sample 1

$4320 \pm 200$

Sample from Site RH 4, Area 1 at $37 \mathrm{~cm}$ depth (lowest level at site). Comments: sample counted in small counter. MASCA corrected date: 3110 to $3010 \pm 210$ BC.

\section{P-2741. Sample 2}

$\mathbf{4 0 3 0} \pm \mathbf{5 0}$

Sample from Site RH 4, Area 7 at $20 \mathrm{~cm}$ depth. Part of charcoal lens with ashes, $3 \mathrm{~cm}$ thick, possibly floor of hut. Comment: MASCA corrected date: $2670,2630 \pm 60$ BC.

\section{Ghana}

\section{P.2746. Gao Lagoon, Sample Gao 77-3}

$5860 \pm 60$ $\delta^{13} C_{w}=+21.02 \pm 0.66 \%$

Shell sample from later Neolithic shell midden with pottery at Gao Lagoon, Ghana $\left(5^{\circ} 40^{\prime} \mathrm{N}, 0^{\circ} 2^{\prime} \mathrm{E}\right)$. Sample is from waterlogged deposit in Pit D, Layer $6 \mathrm{E}$. Coll and subm 1977 by J Dombrowski, Dept Archaeol, Univ Ghana, Legon. Comments: sample corrected for fractionation, but no reservoir correction made. MASCA corrected date: 4760 , 4710 to $4690 \pm 60 \mathrm{BC}$. (JD): estimated date of midden and surrounding deposits: $1000 \mathrm{BC}$ to AD 1500 . No European imports present.

\section{Ga Ji, E Lake Turkana series}

\section{Kenya}

Charcoal from sandy beach deposits of high-level E Lake Turkana, Marsabit Dist, Kenya (3 $\left.56^{\prime} \mathrm{N}, 36^{\circ} 14^{\prime} \mathrm{E}\right)$. Coll 1977 by J Barthelme; subm 1977 by D W Phillipson, British Inst in Eastern Africa, Nairobi.

\section{P-2609. Sample A, Ga Ji/2}

$3970 \pm 60$

Sample from hearth in Spit 7, Sq 3. Comments: $\mathrm{NaOH}$ pretreatment. MASCA corrected date: $2580 \pm 60$ вс. (DWP): horizon includes remains of domestic animals and has ceramic affinities with sites further S. 
P-2610. Sample B, Ga Ji/4

Sample from Levels $1 / 3, \mathrm{Sq} 1$ to 4 at $2.5 \mathrm{~m}$ below present ground level. Comments: MASCA corrected date: 2480 to $2440 \pm 60$ BC. (DWP): first stratified deposit of Nderit pottery assoc with domestic fauna. Date may represent early phase in introduction of domestic animals in $\mathrm{E}$ Africa.

\section{Ele Bor Rockshelter series}

Samples from Ele Bor Rockshelter A, Marsabit Dist, Kenya $\left(3^{\circ} 30^{\prime}\right.$ $\mathrm{N}, 38^{\circ} 15^{\prime} \mathrm{E}$ ). Coll and subm 1977 by D W Phillipson. (For general account of later prehistory of this area, see Phillipson, 1972).

\section{P-2612. Sample D}

$630 \pm 50$

Sample from Grid Sq M/5, Level 2, charcoal and ash lens in upper part of rockshelter deposits. Comments: $\mathrm{NaOH}$ pretreatment. MASCA corrected date: $\mathrm{AD} 1320 \pm 50$. (DWP): sample dates late phase in local pastoral Late Stone Age.

\section{P-2614. Sample F}

$1700 \pm 50$

Sample from Grid Sq M/5, Level 3, charcoal lens sealed in rockshelter deposits. Comments: $\mathrm{NaOH}$ pretreatment. MASCA corrected date: $\mathrm{AD} 260 \pm 50$. (DWP): sample should date phase of most intensive pastoralist occupation at site.

\section{P-2613. Sample E}

$1470 \pm 50$

Sample from Grid Sq M/6, Level 4, charcoal lens sealed in rockshelter deposits. Comments: $\mathrm{NaOH}$ pretreatment. MASCA corrected date: $\mathrm{AD} 540 \pm 60$. (DWP): sample dates early phase of local pastoral Late Stone Age before environmental deterioration led to abandonment of agriculture.

\section{Djenné-djéno series}

\section{Mali}

Djenné-djéno is large Iron Age site in Cercle de Djenné, Mali, W Africa $\left(13^{\circ} 55^{\prime} \mathrm{N}, 4^{\circ} 34^{\prime} \mathrm{W}\right)$. Site is one of richest in W Africa, containing much floral and faunal material, but life span of site is unknown. Samples coll 1977 by R J McIntosh; subm 1977 by S K McIntosh, Dept Anthropol, Univ California, Santa Barbara.

General Comments: all samples except P-2742 were counted in small counter. (SKM): previous series dated by Radiocarbon, Ltd: RL-794, modern; RL-806, $830 \pm 140$; RL-807, $2160 \pm 180$; RL-808, $1570 \pm 110$; RL-950, $820 \pm 180$ (pers commun, C S Tucek). These series provide first sequence of dates for W Africa and will bear on chronology of indigenous African urbanization as well as on domestication of African rice. Possible contamination by insect burrowing.

\section{P-2682. Sample 15}

$1430 \pm 170$

Charcoal of branches and brush from Pit Mound 1, Level 16 bottom at $1.890 \mathrm{~m}$ depth, immediately NE of Funerary Jar 12, containing infant 
burial. Comments: MASCA corrected date: AD $570 \pm 170$. (SKM): dates jar and possibly partition to House 6 .

\section{P-2679. Sample 21}

$1660 \pm 150$

Charcoal of branches and brush from probable hearth in Pit Mound 1, Level 23 at $3.30 \mathrm{~m}$ depth. Comment: MASCA corrected date: AD 290 to $320 \pm 150$.

\section{P-2742. Sample 24/25}

$$
1910 \pm 50
$$

Charcoal from Pit Mound 1, Level 24. Sample 24 is from possible hearth at $3.515 \mathrm{~m}$ depth; Sample 25 is from large charcoal concentration at $3.745 \mathrm{~m}$ depth. Comments: MASCA corrected date: $\mathrm{AD} 90 \pm 50$. (SKM): date of stratum expected to be early or mid-first millennium AD.

\section{P.2772. Sample 22}

$920 \pm 150$

Charcoal from Pit Mound 2, transitional between Levels 10 and 11 , ca $0.5 \mathrm{~m}$ NNW of cranium of Skeleton 13. Comment: MASCA corrected date: $\mathrm{AD} 1040 \pm 160$.

\section{Somalia}

P-2611. Hafun Main site, Sample C

$2030 \pm 60$

Charcoal from Hafun Main site, Iskushubaan Dist, Somalia $\left(10^{\circ} 25^{\prime}\right.$ $\left.\mathrm{N}, 51^{\circ} 16^{\prime} \mathrm{E}\right)$. Sample is part of contents of pottery vessel MS V (4), used as baking oven and set into sandy deposit at 1 to $2 \mathrm{~m}$ depth. Site is probably identifiable with port of Opone on Periplus of Erythrean Sea (Chittick, 1976). Coll 1977 by M C Smith; subm 1977 by D W Phillipson. Comments: NaOH pretreatment. MASCA corrected date: 110 to $70 \pm$ $60 \mathrm{BC}$.

\section{Wisconsin}

\section{United States}

\section{Rehbein series}

Samples are from Rehbein I Mound Group (47-Ri-81), burial mounds at Rehbein, Forest Township, Richland Co, Wisconsin $\left(43^{\circ} 33^{\prime}\right.$ $\left.10^{\prime \prime} \mathrm{N}, 90^{\circ} 39^{\prime} 40^{\prime \prime} \mathrm{W}\right)$, belonging to transitional phase between Hopewellian and Effigy Mound climaxes of Middle (AD 500 to 700) and Late (AD 600 to 800) Woodland periods. This phase is poorly known in Wisconsin. Samples coll 1977 by Barbara Mead; subm 1977 by J E Freeman, State Hist Soc, Wisconsin, Madison.

\section{P.2777. $\delta^{13} \mathrm{C}=+0.95 \pm 0.21 \%$}

Charcoal from Features 7 and 12 , Mound 5 at 28 to $38 \mathrm{~cm}$ below top of mound. Sample was mixed with cremation burial in linear mound. Comments: $\mathrm{NaOH}$ pretreatment. MASCA corrected date: AD 780 to 800 \pm 40. (JEF): Spring Hollow Cord-Marked vessel from Early Late Woodland period was assoc with cremation. Expected date: AD 600 to 800 . Possible root contamination. 


\section{P-2776. Feature 10, Mound 3}

$1710 \pm 35$

Outer rings of log, probably Quercus alba, from Feature 10, Mound 3. Sample is part of $\log$ and bark roof over burial pit in conical mound at ca $91 \mathrm{~cm}$ below top of mound. Comments: $\mathrm{NaOH}$ pretreatment. MASCA corrected date: AD $260 \pm 40$. (JEF): sample assoc with triangular projectile points and a miniature Levsen Punctated vessel of Late Middle to Early Late Woodland period. Expected date: AD 500 to 700 . Possible root contamination.

\section{Las Flores series}

\section{Puerto Rico}

Samples from Early Ostionoid-Saladoid village and ball court at Coamo, Puerto Rico (18 $8^{\circ} 3^{\prime} \mathrm{N}, 66^{\circ} 22^{\prime} \mathrm{W}$ ). Coll 1975 and 1976; subm 1976 by J J Ortiz-Aguilú, Dept Anthropol, Univ Pennsylvania, Philadelphia.

\section{P.2606-A. PRLF 76-C9}

$200 \pm 170$

Ash from Unit TA-37, W wall, Layer II at 17 to $19 \mathrm{~cm}$ below surface and 45 to $74 \mathrm{~cm}$ from NW stake. Comments: sample counted in small counter. MASCA corrected date: AD $1650 \pm 170$. (JJO-A): may date most recent occupation of site. Date later than expected.

P-2599. PRLF 76-C8

$$
600 \pm 45
$$

Ash from Unit Ta-19, W wall, Layer III at 17 to $20 \mathrm{~cm}$ below surface. Comments: MASCA corrected date: AD $1340 \pm 50$. (JJO-A): may date Burial \#1 and provide information on social structure of community. Date consistent with archaeol expectations.

P-2595. PRLF 76-C1

$$
990 \pm 50
$$

Charcoal from Unit TA-11, W wall, Layer $V$ at $27 \mathrm{~cm}$ below surface. Comments: NaOH pretreatment. MASCA corrected date: AD 980 to 1000 \pm 50 . Rootlets removed by hand. (J.jO-A): may date major purposeful disturbance during end of second (?) main occupation. Expected date: ca $\mathrm{AD} 740$ to 800 .

\section{P-2729. PRLF 75-C38}

$1060 \pm 45$

Charcoal from concentration within stratum, Unit TA-38, W wall, Layer IX at 130 to $136 \mathrm{~cm}$ below surface. Comments: MASCA corceled datc: $\mathrm{AD} 930 \pm 45$. (JJO-A): sample should date beginning of last major occupation and help determine date of initial construction of ball comet. Date expected to be roughly contemporaneous with P-2598 (below).

\section{P-2598. PRLF 76-C20}

$1000 \pm 45$

Charcoal extracted from Hearth Feature $\not ⿰ 7$ in Unit TA-37, Level "K", Layer VIIB at 112 to $118 \mathrm{~cm}$ below surface. Comments: NaOH pretreatment. MASCA convected date: $\mathrm{AD} 980 \pm 50$. (JJO-A): assoc with carliest level of second major occupation and ball court. Date expected to be roughly contemporaneous with P-2729 (above); see commont for P-2607 (below). 
P-2596. PRLF 76-C6

$1170 \pm 45$

Almost pure charcoal from Unit TA-9, W wall, Layer VII at $42 \mathrm{~cm}$ below surface, closely assoc with ceramics. Matrix was stratum of sandy silt, underlain by gravel. Comments: MASCA corrected date: $\mathrm{AD} 800$ to $820 \pm 45$. (JJO-A): expected date: ca AD 500 to 700 .

\section{P-2607. PRLF 76-C10/C11}

White ash from ball court, Unit TA-37, W wall, Layer VIIIB at $99 \mathrm{~cm}$ below surface. Comments: MASCA corrected date: AD $600 \pm 45$. (JJO-A): this level is one of earliest at site; sample may date construction of ball court. Date consistent with archaeol expectations, but not contemporary with P-2598 and P-2729 (above) as expected.

\section{Playa de los Muertos series}

\section{Honduras}

Samples from superimposed living floors at Playa de los Muertos in Sula Valley of NW Honduras (140 18 $\left.19^{\prime \prime} \mathrm{N}, 87^{\circ} 54^{\prime} 24^{\prime \prime} \mathrm{W}\right)$. Coll 1975 and subm 1976 by N C Kennedy, Univ Illinois at Urbana.

General Comments (NCK): deposits dated by stylistic anaiysis of pottery to phases of Early and Middle Formative complexes of $\mathrm{S}$ Mesoamerica (Kennedy, 1977). Possible humic acid contamination.

\section{P-2747. Sample 1}

$2170 \pm 35$

Charred wood from Operation $\mathrm{H}$, Lot 12 at 2.2 to $2.4 \mathrm{~m}$ below datum. Comments: MASCA corrected date: 380,300 to $250 \pm 35 \mathrm{BC}$. (NCK): (Late) Middle Formative cultural affiliation.

P-2748. Sample 2

$2300 \pm 140$

Charcoal from Operation $\mathrm{H}$, Lot 13 at 2.4 to $2.6 \mathrm{~m}$ below datum. Comments: sample counted in small counter. MASCA corrected date: $430 \pm 150 \mathrm{BC}$. (NCK): Middle Formative cultural affiliation.

\section{P.2749. Sample 3/4}

$2160 \pm 40$

Charcoal from Operations $\mathrm{H}$ and $\mathrm{H}^{\prime \prime}$, Lot 14 at 2.6 to $2.8 \mathrm{~m}$ below datum. Comments: samples combined after pretreatment. MASCA corrected date: 380,300 to $250 \pm 40$ BC. (NCK): (Early) Middle Formative cultural affliation.

P-2750. Sample 5

$2310 \pm 180$

Charcoal from Operation $\mathrm{H}$, Lot 17 at 9.2 to $3.4 \mathrm{~m}$ below datum. Comments: sample counted in small counter. MASCA corrected date: $430 \pm 180$ вC. (NCK): Early Formative cultural affiliation.

\section{Huachichocana series}

\section{Argentina}

Samples from Cave CH III at Huachichocana in Jujuy Prov, N Argentina $\left(23^{\circ} 45^{\prime} \mathrm{S}, 65^{\circ} 38^{\prime} \mathrm{W}\right)$. Coll $197^{\prime}$ to 1976 ; subm 1974 to 1978 by $A$ A Fernández Distel, Inst Antropol Univ Buenos Aires (Aguerre, Fennánclez Distel, and Aschero, 1973; 1975; Fernández Distel, 1974). 
Charcoal from Level E 1 at ca $1.15 \mathrm{~m}$ depth, assoc with earliest occurrence of pottery in cave. Comments: sample counted in small counter. MASCA corrected date: AD $570 \pm 190$. (AAFD): date younger than expected.

\section{P-2280. Sample CH III E}

$\mathbf{8 4 2 0} \pm \mathbf{5 3 0}$

Partially carbonized wood from Level E 3 at ca $1.7 \mathrm{~m}$ depth, representing first human occupation of cave, preceramic phase assoc with domesticated plants. Comments: sample counted in small counter. Date beyond range of MASCA correction factors now available (Oct 1980).

\section{P-2236. Sample CH III E bis}

$9340 \pm 120$

Charcoal from Level E 3 at ca $1.8 \mathrm{~m}$ depth. Cultural assoc as for P-2280 (above). Comment: date beyond range of MASCA correction factors now available (Oct 1980).

\section{P-2608. Sample CH III E 3}

$$
\delta^{13} C_{w}=+7.75 \pm 0.19 \%
$$

Cob, stalk, and leaves of Zea mays from E 3, earliest occupation level. Comments: sample counted in small counter. MASCA corrected date: $\mathrm{AD} 410 \pm 190$. (AAFD): dated to understand origin and antiquity of domesticated corn in South America. Date younger than expected.

\section{Ecuador}

\section{P-2761. Anllulla Sample 3}

$4020 \pm 220$

Charcoal from shell mound at Anllulla, $30 \mathrm{~km}$ SW of Guayaquil in Guayas Prov, Ecuador ( $\left.2^{\circ} 33^{\prime} 24^{\prime \prime} \mathrm{S}, 80^{\circ} 10^{\prime} 4^{\prime \prime} \mathrm{W}\right)$. Sample is from Cut A at $3.1 \mathrm{~m}$ depth of mound, $4 \mathrm{~m}$ high, belonging to Valdivia/Machalilla cultures. Should date earliest ceramic phase of Valdivia culture (Meggers, Evans, and Estrada, 1965). Coll and subm 1973 by E H Lubensky, US Embassy, San Salvador. Comments: sample counted in small counter. MASCA corrected date: $2620 \pm 220$ BC. (EHL): previous series dated by Inst Physical and Chem Research, Saitama, Japan: N-2907 (0.2 to $0.3 \mathrm{~m}$ depth), $1420 \pm 70 ; \mathrm{N}-2908$ (1.8m depth), $3660 \pm 95 ; \mathrm{N}-2909$ (3.3m depth), $3630 \pm 105$. N-2909 is from same deposit as P-2761, but from slightly younger level.

\section{GEOLOGIC SAMPLES}

Spain

$\begin{array}{rr}\text { Spain } & \mathbf{3 2 , 4 0 0}+\mathbf{1 9 8 0} \\ \text { P-2540. Canet Cave } & { }^{1 s} C_{w}=+17.80 \pm 0.46 \%\end{array}$

Snail shells (tentatively id as Tudorella ferruginea, Vallonia pulchella, and Cryptomphalus asperus) from Canet Cave, Esporles, Mallorca $\left(39^{\circ} 39^{\prime} \mathrm{N}, 6^{\circ} 19^{\prime} \mathrm{E}\right)$. Sample is from Trench \#4 at 20 to $40 \mathrm{~cm}$ depth in terra rossa clay above magnetically reversed interval at 1 to $2 \mathrm{~m}$ depth, thought to be Gothenburg-Laschamp excursion (17,000 to $12,500 \mathrm{yr} \mathrm{BP})$. Coll and subm 1976 by J S Kopper, Dept Sociol and Anthropol, Long 
Island Univ, Greenvale, New York. Comments: corrected for isotopic fractionation, but no reservoir correction made. Date beyond range of MASCA correction factors now available. (JSK): date helps correlate unique paleomagnetic $\log$ from this site and should, on stratigraphic grounds, be 10,000 to $6000 \mathrm{BP}$; for previous date from Trench \#1, see P-2408 (R, 1978, v 19, p 225).

\section{P-2705. Cova dets Alexandres}

$4070 \pm 250$

Charcoal from Cova dets Alexandres, Escorca, Mallorca $\left(39^{\circ} 48^{\prime} \mathrm{N}\right.$, $6^{\circ} 30^{\prime} \mathrm{E}$ ). Sample is from 60 to $70 \mathrm{~cm}$ level of $6 \mathrm{~m}$ core in interior facies of cave sediments. Coll and subm 1977 by J S Kopper. Comments: sample counted in small counter. MASCA corrected date: 2800 to 2690 \pm 260 BC. (JSK): dated as part of reconstruction of Upper PleistoceneHolocene magnetic history and may correlate with adjacent paleomagnetic log, in which case "Magnetic Age" at $60 \mathrm{~cm}$ should be ca $3500 \mathrm{yr}$ вP (Kopper and Creer, 1973).

\section{United States}

New Jersey

$4650 \pm 70$

P.2722. Ocean City Sewer Outfall, Sample $3{ }^{13} C_{w}=+0.89 \pm 0.09 \%$ o

Peat from ca $4.15 \mathrm{~m}$ depth of Core 9 at ca $9 \mathrm{~m}$ below modern sea level in sewer outfall ca $3000 \mathrm{~m} \mathrm{E}$ of 46 th St, Ocean City, New Jersey $\left(39^{\circ} 17^{\prime} \mathrm{N}, 74^{\circ} 33^{\prime} \mathrm{W}\right)$, on line $\mathrm{S} 48^{\circ} 32^{\prime} 0^{\prime \prime} \mathrm{E}$ in corridor ca $30 \mathrm{~m} \mathrm{~S}$ of that line. Coll and subm 1977 by Barbara Liggett, Rutgers Univ, New Brunswick, New Jersey. Comments: MASCA corrected date: 3470 to $3430,3400 \pm 80$ BC. (BL): sample dated as part of off-shore environmental project.

\section{REFERENCES}

Aguerre, A M, Fernández Distel, A A, and Aschero, C A, 1973, Hallazgo de un sito acerámico en la quebrada de Inca cueva (Provincia de Jujuy): Soc Argentina Antropol Relaciones, v 7, p 197-235.

Antropol 1975 , Comentarios sobre nuevas fechas en la chronología arqueológica precerámica de la provincia de Jujuy: Soc Argentina Antropol Relaciones, v 9, p $211-213$.

Balmuth, M S and Tylecote, R F, 1976, Copper and bronze in Sardinia: Excavation and analysis: Jour Field Archaeol, v 3, p 195-201.

Bcrnabò Brea, Luigi, 1980, Beziehungen zu Malta, Sizilien und den äolischen Inseln, in Thimme, Jürgen, ed, Kunst und Kultur Sardiniens vom Neolithikum bis zum Ende der Nuraghenzeit: Karlsruhe, p 192-200.

Betancourt, P P and Weinstein, G A, 1976, Carbon-14 and the beginning of the late Bronze Age in the Acgean: Am Jour Archaeol, v 80, p 329-348.

Chittick, H N, 1976, Report on archaeological reconnaissance in Somalia 1975: Azania, v 11, p $117-131$.

Fanning, Thomas, 1973, Excavations at Reask, County Kerry: Jour Kerry Archaeol

Hist Soc, v 6, p 5-8.
1975, Excavations at Reask, preliminary report-seasons 1973-5: Jour Kerry Archacol Hist Soc, v 8, p 5-10.

Fernández Distel, A A, 1974, Excavaciones arqueológicas en las cuevas de Huachi chocana, Dep de Tumbaya, Prov de Jujuy, Argentina: Soc Argentina Antropol Relaciones, v 8, p 101-134.

Fishman, Bernard, Forbes, Hamish, and Lawn, Barbara, 1977, University of Pennsylvania radiocarbon dates XIX: Radiocarbon, v 19, p 188-228.

Fishman, Bernard and Lawn, Barbara, 1978, University of Pennsylvania radiocarbon dates XX: Radiocarbon, v 20, p 210-233. 
Kennedy, N C, ms, 1977, On the frontier at Playa de los Muertos, Honduras: Paper presented at 42nd ann mtg of Soc Am Archaeol, New Orleans, 1977.

Kopper, J S and Creer, K M, 1973, Cova dets Alexandres: Caves and Karst, v 15, p $13-20$.

Lehavy, Y M, 1974, Excavations at neolithic Dhali-Agridhi, in Stager, L E, Walker, Anita, and Wright, G E, eds, American expedition to Idalion, Cyprus. First preliminary report: Seasons of 1971 and 1972: Cambridge, Massachusetts, The American Schools of Oriental Research, p 95-102.

Meggers, B J, Evans, Clifford, and Estrada, Emilio, 1965, The early formative period of coastal Ecuador: The Valdivia and Machalilla phases: Washington, Smithsonian Contri to Anthropol, v 1, 234 p.

Michael, H N, 1976, Radiocarbon dates from Akrotiri on Thera: Temple Univ Aegean symposium, v l: Philadelphia, Temple Univ, p 7-9.

1978, Radiocarbon dates from the site of Akrotiri, Thera, 1967-1977, in Doumas, Christos and Buchelt, H C, eds, Thera and the Aegean World I: London, Thera and the Aegean World, p 791-795.

Michael, H N and Ralph, E K, 1974, University of Pennsylvania radiocarbon dates XVI: Radiocarbon, v 16, p 198-218.

Phillipson, D W, 1972, The later prehistory of eastern and southern Africa: New York, Africana Pub Co, 323 p.

Ralph, E K, Michael, H N, and Han, M C, 1973, Radiocarbon dates and reality: MASCA Newsletter, v 9, no. 1, p 1-20.

Segre, Eugenia and Piperno, Marcello, 1975, Scavi alla Grotta dell'Uzzo. Relazione prelim: Sicilia Archaeol, v 7, p 11-16.

Taramelli, Antonio, 1918, L'Officina fusoria di Ortu Commidu: Monumenti Antichi, v $25, \mathrm{p} 107-130$

Tosi, Maurizio, 1975, Note on the distribution and exploitation of natural resources in ancient Oman: Jour Oman Studies, v 1, p 187-206.

Weinstein, G A and Betancourt, P P, 1978, Problems of interpretation of the Akrotiri radiocarbon dates, in Doumas, Christos and Buchelt, $\mathbf{H ~ C}$, eds, Thera and the Aegean World I: London, Thera and the Aegean World, p 807-814.

Weinstein, G A and Michael, H N, 1978, Radiocarbon dates from Akrotiri, Thera: Archaeometry, v 20, p 203-209. 